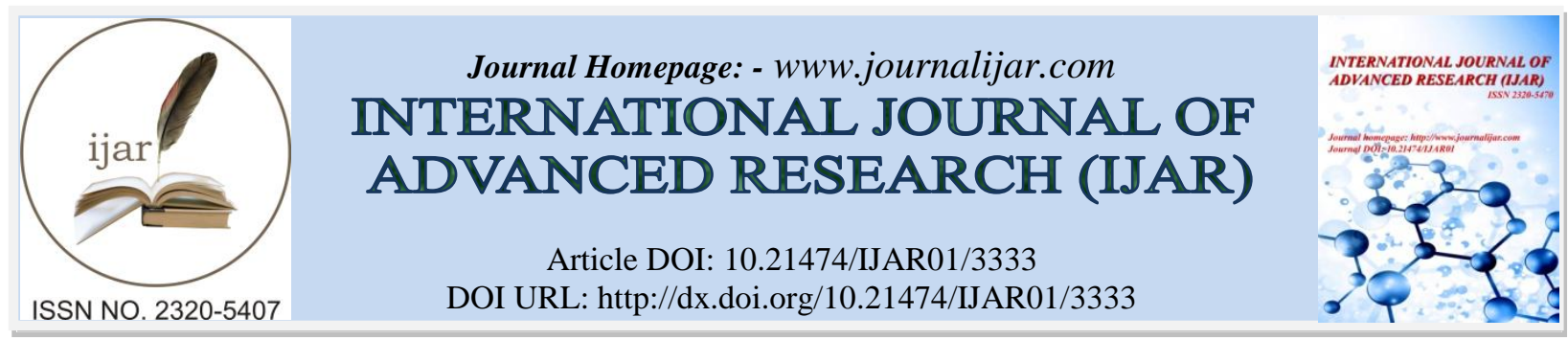

RESEARCH ARTICLE

\title{
A WIDENED TAX BASE - REMEDY FOR ECONOMIC DEVELOPMENT AND DISTRIBUTIONAL EQUITY IN INDIA : AN ANALYSIS.
}

1. Practising Chartered Accountant

2. Associate Professor PG Department of Commerce, Utkal University.

3. Research Fellow, PG Department of Commerce, Utkal University.

\section{Manuscript Info}

Manuscript History

Received: 25 December 2016

Final Accepted: 28 January 2017

Published: February 2017

Key words:-

Direct taxes, Corporate Taxes, Indirect

Taxes, GDP

\begin{abstract}
Personal income tax base in India is very low as compared to other emerging and developed nations. During the year 2010-11 the total returned filed was about $3.3 \%$ of the total population of India whereas the ratio of returned filed by Singapore was 39\%, USA 46\%, and New Zealand $75 \%$. Taxation serves the purpose of promoting economic development by curbing consumption, increasing the incentive to save and invest and transferring resources from the hand of the public to the government for investment and public finance purposes. Initiative on widening of Tax base should be honest and vigorous one so that the entire potential tax payers comes under its purview which in turn shall contribute to national tax revenue. So, there is a need for creating transparent, friendlier and less discriminatory administrative system. In light of the above the relationship and trend among personal income tax, corporate Tax , indirect and GDP are analysed and it is suggested for Expansion of Scope for Presumptive Taxation, Discourage Cash Economy/ Encourage Cashless economy, Tax on Agriculture Income, Imposition of more Tax on High Net Worth Individuals, Imposition of Property Tax, Gradual Reduction/Withdrawal of Various Subsidies And Exemptions and Expanding the Tax Base.
\end{abstract}

Copy Right, IJAR, 2017,. All rights reserved.

\section{Introduction:-}

Resource is the critical factor for every economy whether developed or least developed. Resource mobilisation is key to not only to the country but also for corporate and to all stake holders at large. It means collecting the funds from various internal and external sources for financing and executing development plans. The importance of resource mobilisation in emerging or under developed countries lies in curtailing consumption and augmenting savings for an accelerated investment in the interest of community. It is essential for the purpose of removing maladjustment between supply and demand of goods and services in order to avoid inflation and balance of payment difficulties.

Taxation serves the purpose of promoting economic development by curbing consumption, increasing the incentive to save and invest and transferring resources from the hand of the public to the government for investment and public finance purposes. It also reduces economic inequalities and mobilising economic surplus. 
In India, additional taxation refers to additional resource mobilisation by levying additional taxes or through changes in the tax base and greater efforts at tax collection and by raising the administered prices of goods produced by public enterprises. Additional taxation has been one of the key sources of financing the expenditure during the five year plans.

No doubt the country needs larger tax revenue for financing its development plans but there are certain limitations to increase the tax revenue at a faster rate than in national income. The share of direct taxes in total tax revenue declined from $37 \%$ in $1950-51$ to $14 \%$ in $1984-85$. Gradually the share has increased from $14 \%$ in $1984-85$ to $51 \%$ in the year 2014-15. But still the share is quite low in comparison to the existing international scenario. This indicates more dependence on indirect taxes. Indirect taxes raise prices which lead to inflationary consequences. The lower middle income groups and poorer sections of the society are being reduced to abject poverty with the reduction in their purchasing power due to increased indirect taxes. On the other hand, the burden of direct taxes has been declining on the upper middle and higher income groups. They are becoming better off. The scope for raising additional revenues through mere changes in the tax rates is limited. Moreover, the main drawback of higher taxation is that it leads to tax evasion thereby leading to creation of black money. There is considerable scope for reducing tax evasion, rationalising tax laws, streamlining tax administration and widening the tax base in the urban sector and tapping the surpluses of the affluent section of the farming community in rural sector of India.

So far as indirect taxes are concerned, there is the need for an adjustment and rationalisation of tax rates and GST is a step in this direction. Greater efforts are needed to explore ways of raising revenues by tapping rural income of large farmers and large land holders.

\section{Objectives, Review Of Literature And Research Methodology:-}

The personal income tax base in India is very low as compared to other emerging and developed nations. The relevance of the study emanates from the fact that the contribution of indirect tax in total tax revenue collection in India is quite high in comparison to international scenario. This study aims to ascertain the tax structure, the ratio of direct taxes and indirect tax in total tax revenue collection, and impact of present tax system on lower income group and poor section of the society.

We try to explore the findings some of the studies. Gupta (2009) clarified in the trends in personal income tax reforms have a favourable impact on the growth of personal income tax. Nagaraj (2010) did a comparative study of direct tax revenue to GDP in developed and developing countries in the year 2008. It was $11 \%$ for India and the ratio was $42.9 \%, 43.1 \%$, and 36.4\% in Australia, France, and Germany respectively. Reason of Low ratio is due to collection of maximum tax from middle income group individuals. The major reasons for tax evasion are exorbitant rate, complex and complicated tax structure and inefficient and corrupt government administration. Wadhwa and Pal (2012) has found that the causes of tax evasion are high tax rates, corruption in public sector units, multiple tax rates and inefficient tax authorities. It has been suggested that reduction in tax rates, simplifications of tax laws, removal of loopholes in the tax system and to some extent proper processing of information available the under the annual information return can be best tool for improving Indian tax compliance. Dey (2014) pointed out that the structural shift in composition of tax revenue of central Government from indirect taxes to direct taxes. This can be considered as a positive development on the assumption that direct taxes are more equitable in impact and pro-poor as compared to indirect taxes. The Tenth Report of Public Accounts Committee (2014-15) shows that the numbers of tax payers in financial year 2006-07 were 313 lakhs and it increased to 335.80 lakhs by 2010-11. It shows an uptrend of $7.3 \%$ and average annual growth of @ 1.8\%. The direct tax collections was Rs. 2,30,181 Crore and Rs. 4,45,995 Crore during the same period and it shows an overall uptrend of $93 \%$ and average annual growth of @ 23.33\%. Third Report of TARC (2014), and FICCI (2015) gave various reasons for declining tax payer base. The important cause for declining tax tax payer base are change in basic exemption limit, grant of additional exemption, huge unorganised sector, and culture of large scale cash transaction. There is huge gap between number of working company as per ROC Records (10.17 lakhs) and corporate tax payers registered with IT department (7 lakhs). The report suggested for wider tax base to achieve fiscal consolidation and higher tax GDP ratio, to meet the fiscal target of growth in tax collection, to enable government to undertake planned investment in infrastructure and other areas for growth and development of country, and to lower the burden of the existing tax payer. The NIPFP (2015) report indicates that the difference between potential and actual return filed is very high. The suggestion is to widen the tax base by increasing in penalty rate or reduction in tax which results in burden on people to file return, and reduction in tax rate will bring more persons in to tax regime. Fiscal Policy Strategy Statement (Fiscal policy in 2016-17) clarified that the effort of the Government has shifted from curtailing expenditure to generating higher revenues for 
reducing the fiscal deficit and to raise additional resources to implement Government policy priorities. To achieve this, the Government policy is oriented broadly in favour of minimizing exemptions and broadening the tax base for a higher tax to GDP ratio.

The data collected from the secondary sources and simple growth trend and different ratio are being used for the analysis.

\section{Importance Of Direct Taxes Over Indirect Taxes In A Developing Or Under Developed Economy:-}

Taxation is the main source of revenue. Its classification into direct and indirect taxes is very essential because of their effects on production, distribution and consumption are different. In advanced countries of the world, the major part of their total tax revenue (about 70\%) comes from direct taxes and about 30 percent in the form of indirect taxes. In contrast developing or under developed countries have to heavily rely on indirect taxes for revenue collection. Here indirect taxes account for 70 to 80 percent of the total revenue collection.

Direct taxes is paid entirely by those persons on whom they are imposed, and it cannot be shifted to others whereas indirect taxes which are later shifted to others by paying initially by those on whom they are imposed. Direct taxes are progressive in their rates which implies that higher incomes are taxed heavily and lower incomes lightly. The principle of equity which says that broader shoulder should bear a heavier money burden of a tax is satisfied. Direct taxes can be and are taxed according to the "ability to pay" of the tax payers. It, thus, satisfy the equity principle. On the hand indirect taxes are regressive in nature which will remain constant irrespective with the level of income and are equal for all. Elasticity in direct taxes implies that more revenue is collected by the government through direct taxes as the incomes of the people increases because larger income segments are taxes automatically at higher rates. It helps in collecting larger revenue. Direct taxes satisfy the cannons of economy convenience and certainty. They are economical in collection and administration hence the revenue rises without any corresponding addition to cost of collection. Direct taxes are paid directly to government. So there is no scope for any leakage. Though the direct taxes pinch the tax payer, the direct tax payers are more attentive towards the utilisation of their funds. People become more conscious of their rights and obligations. Thus there is a great chance to improve the educative value and civic consciousness. Direct taxes bring flexibility in their rates from time to time to avoid their adverse effect on willingness and ability to work, save and invest. Exemptions and concessions are used as tools to avoid the adverse effects of direct taxes on production, distribution and consumption.

\section{Data Analysis And Findings:-}

\section{Direct Tax (Data Analysis):-}

If a tax is intended to be paid by the person whom it is imposed is called direct tax. Direct taxes are imposed on receipts of income. Direct taxes are of various types like corporate tax, income tax wealth tax, property tax etc. Out of them corporate tax and income tax are major contributors to the revenue of the Government.

Table No 1:-

\begin{tabular}{|c|c|c|c|c|}
\hline \multicolumn{5}{|c|}{ Contribution Of Direct Taxes \& Indirect Taxes To Total Tax } \\
\hline \multicolumn{5}{|c|}{ (Rs. In Crores) } \\
\hline Financial Year & Direct Tax & Indirect Tax & Total Tax & Direct Tax to Total Tax (\%) \\
\hline $2000-01$ & 68,305 & $1,19,814$ & $1,88,119$ & $36.31 \%$ \\
\hline $2001-02$ & 69,198 & $1,17,318$ & $1,86,516$ & $37.10 \%$ \\
\hline $2002-03$ & 83,088 & $1,32,608$ & $2,15,696$ & $38.52 \%$ \\
\hline $2003-04$ & $1,05,088$ & $1,48,608$ & $2,53,696$ & $41.42 \%$ \\
\hline $2004-05$ & $1,32,771$ & $1,70,936$ & $3,03,707$ & $43.72 \%$ \\
\hline $2005-06$ & $1,65,216$ & $1,99,348$ & $3,64,564$ & $45.32 \%$ \\
\hline $2006-07$ & $2,30,181$ & $2,41,538$ & $4,71,719$ & $48.80 \%$ \\
\hline $2007-08$ & $3,14,330$ & $2,79,031$ & $5,93,361$ & $52.97 \%$ \\
\hline $2008-09$ & $3,33,818$ & $2,69,433$ & $6,03,251$ & $55.34 \%$ \\
\hline $2009-10$ & $3,78,063$ & $2,43,939$ & $6,22,002$ & $60.78 \%$ \\
\hline $2010-11$ & $4,45,995$ & $3,43,716$ & $7,89,711$ & $56.48 \%$ \\
\hline $2011-12$ & $4,93,987$ & $3,90,953$ & $8,84,940$ & $55.82 \%$ \\
\hline $2012-13$ & $5,58,989$ & $4,72,915$ & $10,31,904$ & $54.17 \%$ \\
\hline $2013-14$ & $6,38,596$ & $4,95,347$ & $11,33,943$ & $56.32 \%$ \\
\hline $2014-15$ & $6,95,792$ & $5,43,215$ & $12,39,007$ & $56.16 \%$ \\
\hline $2015-16$ & $7,42,295$ & $7,11,885$ & $14,54,180$ & $51.05 \%$ \\
\hline
\end{tabular}

(Source: IT Department, Govt. Of India) 
In Table-1 data shows the contribution of Direct Taxes to Total revenue. In the year 2000-01 the contribution of direct taxes to total taxes stands at $36.31 \%$ and this ratio has an increasing trend till 2009-10. There has been substantial increase in ratio in $2009-10$ which stands at $60.78 \%$ in spite of the effect of global slowdown. The declining trend of direct tax to total revenue, in principle is not suggested for a developing country. If the direct tax to total tax declines it implies the growth of indirect tax to total tax. The increasing ratio of indirect taxes to total tax adversely affects the purchasing power of lower income group and poor people. That leads to more disparity in the poor and richer.

Figure 1:-

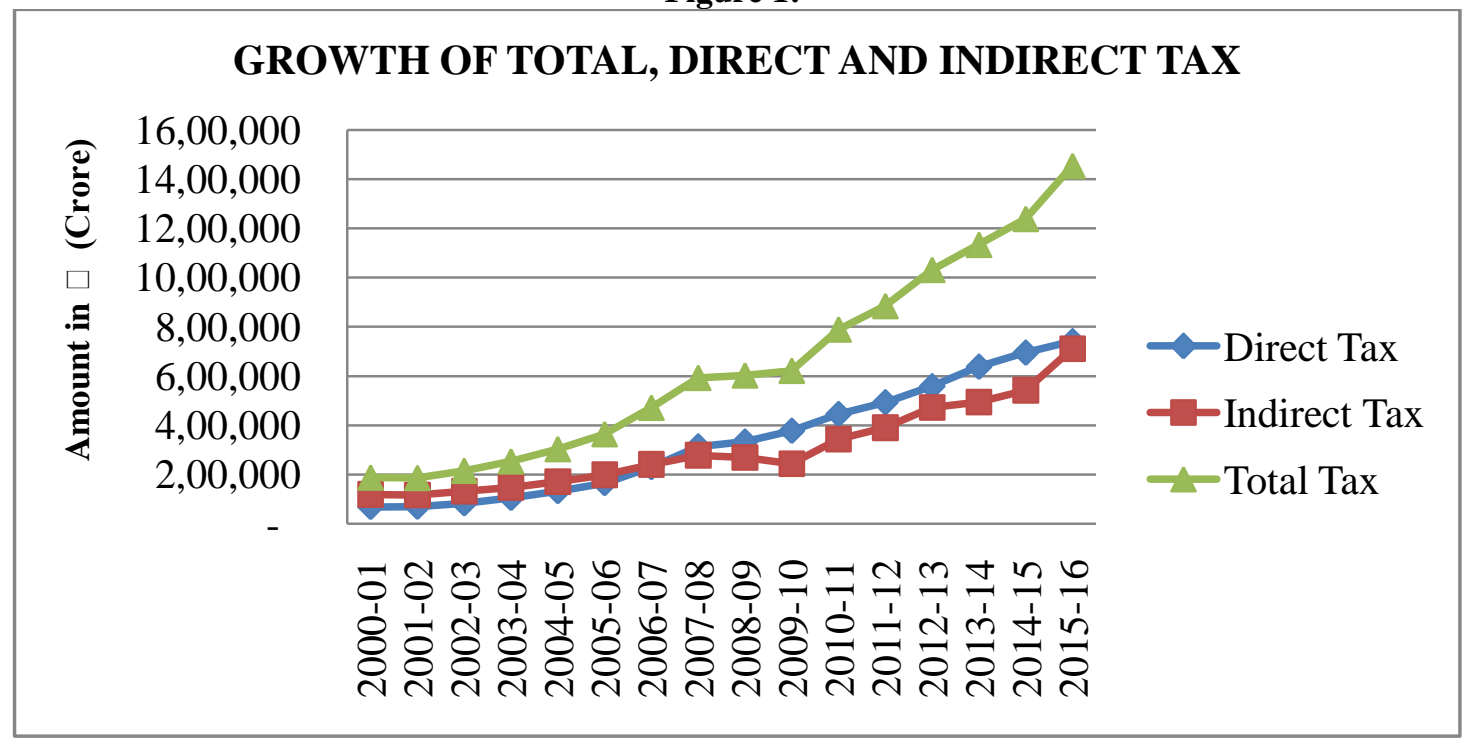

As the Figure-1 show, initially in 2000-01 the direct taxes are less than indirect tax. This trend continues till the mid of 2007-08. After 2007-08 the direct taxes ratio to total tax is started growing. In the year 2009-10 the direct tax is maximum level. The trend remained at higher side as compare to indirect to total tax ratio.

Table No- 2

\begin{tabular}{|c|c|c|c|c|}
\hline \multicolumn{5}{|c|}{ Direct Tax Collection } \\
\hline \multicolumn{7}{|c|}{ (Rs. In Crores) } & Other Direct Tax & Total \\
\hline Financial Year & Corporate Tax & Personal Tax & 845 & 68,305 \\
\hline $2000-01$ & 35,696 & 31,764 & 585 & 83,088 \\
\hline $2001-02$ & 36,609 & 32,004 & 50 & $1,05,088$ \\
\hline $2002-03$ & 46,172 & 36,866 & 140 & $1,32,771$ \\
\hline $2003-04$ & 63,562 & 41,386 & 823 & $1,65,216$ \\
\hline $2004-05$ & 82,680 & 49,268 & 250 & $2,30,181$ \\
\hline $2005-06$ & $1,01,277$ & 63,689 & 240 & $3,14,330$ \\
\hline $2006-07$ & $1,44,318$ & 85,623 & 340 & $3,33,818$ \\
\hline $2007-08$ & $1,93,561$ & $1,20,429$ & 389 & $3,78,063$ \\
\hline $2008-09$ & $2,13,395$ & $1,20,034$ & 505 & $4,45,995$ \\
\hline $2009-10$ & $2,44,725$ & $1,32,833$ & 1,049 & $4,93,987$ \\
\hline $2010-11$ & $2,98,688$ & $1,46,258$ & 990 & $5,58,989$ \\
\hline $2011-12$ & $3,22,816$ & $1,70,181$ & 823 & $6,38,596$ \\
\hline $2012-13$ & $3,56,326$ & $2,01,840$ & 1,030 & $6,95,792$ \\
\hline $2013-14$ & $3,94,678$ & $2,42,888$ & 1,095 & $7,42,295$ \\
\hline $2014-15$ & $4,28,925$ & $2,65,772$ & 1,075 & \\
\hline $2015-16$ & $4,54,419$ & $2,86,801$ & & \\
\hline
\end{tabular}

(Source: IT Department, Govt. Of India)

The Direct tax consists of corporate tax, personal tax and other direct tax. In the year 2000-01, the corporate tax and personal tax variance is small. The ratio of corporate tax increased gradually from Rs. 35,696 crore to Rs. $4,54,419$ crore during the period 2000-01 to 2015-16. In contrast to that the personal tax increased in a slower rate i.e. from 
Rs. 31,764 crore in $2000-01$ to Rs. $2,86,801$ crores during the same period. The other direct tax is not increasing in a constant pace; its trend is volatile as the data shows.

Figure 2:-

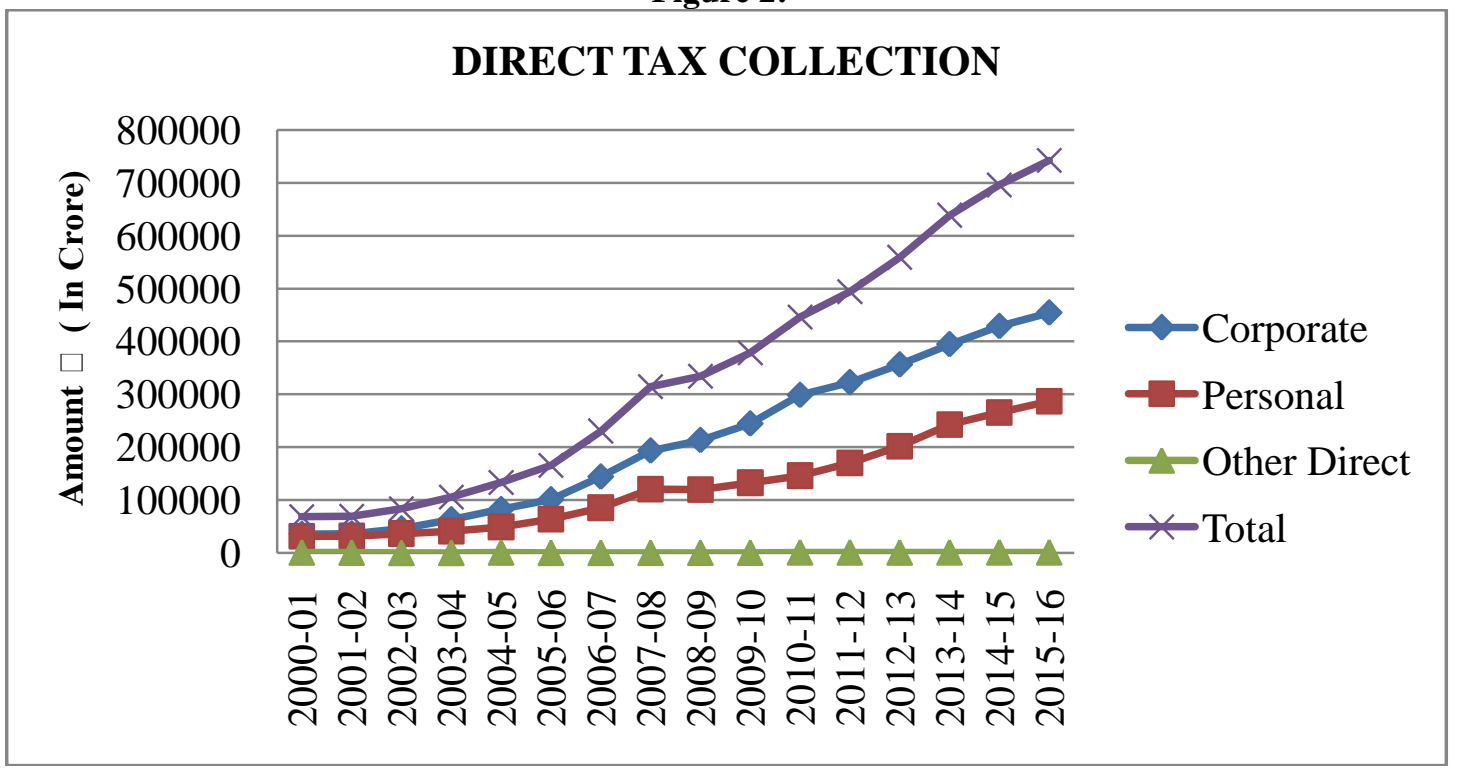

From the direct tax collection figure (Figure -2), it show that corporate tax is growing more in proportion to personal tax. The other direct taxes are stagnant. From the year 2008-09 the collection of all taxes, except other direct taxes are increasing in a better pace as compared to the period 2000-01 to 20007-08. In developed countries, the personal tax is more in comparison to corporate tax collection.

Table No 3:-

\begin{tabular}{|c|c|c|c|c|c|}
\hline \multicolumn{7}{|c|}{ Personal Tax Ratios } \\
\hline $\begin{array}{c}\text { Financial } \\
\text { Year }\end{array}$ & Personal Tax & $\begin{array}{c}\text { Total Direct } \\
\text { Tax }\end{array}$ & $\begin{array}{c}\text { Personal Tax to } \\
\text { Total Direct Tax } \\
(\%)\end{array}$ & $\begin{array}{c}\text { Total Tax (Direct + } \\
\text { Indirect) }\end{array}$ & $\begin{array}{c}\text { Personal Tax to Total } \\
\text { Tax (\%) }\end{array}$ \\
\hline $2000-01$ & 31,764 & 68,305 & $46.50 \%$ & $1,88,119$ & $16.89 \%$ \\
\hline $2001-02$ & 32,004 & 69,198 & $46.25 \%$ & $1,86,516$ & $17.16 \%$ \\
\hline $2002-03$ & 36,866 & 83,088 & $44.37 \%$ & $2,15,696$ & $17.09 \%$ \\
\hline $2003-04$ & 41,386 & $1,05,088$ & $39.38 \%$ & $2,53,696$ & $16.31 \%$ \\
\hline $2004-05$ & 49,268 & $1,32,771$ & $37.11 \%$ & $3,03,707$ & $16.22 \%$ \\
\hline $2005-06$ & 63,689 & $1,65,216$ & $38.55 \%$ & $3,64,564$ & $17.47 \%$ \\
\hline $2006-07$ & 85,623 & $2,30,181$ & $37.20 \%$ & $4,71,719$ & $18.15 \%$ \\
\hline $2007-08$ & $1,20,429$ & $3,14,330$ & $38.31 \%$ & $5,93,361$ & $20.30 \%$ \\
\hline $2008-09$ & $1,20,034$ & $3,33,818$ & $35.96 \%$ & $6,03,251$ & $19.90 \%$ \\
\hline $2009-10$ & $1,32,833$ & $3,78,063$ & $35.14 \%$ & $6,22,002$ & $21.36 \%$ \\
\hline $2010-11$ & $1,46,258$ & $4,45,995$ & $32.79 \%$ & $7,89,711$ & $18.52 \%$ \\
\hline $2011-12$ & $1,70,181$ & $4,93,987$ & $34.45 \%$ & $8,84,940$ & $19.23 \%$ \\
\hline $2012-13$ & $2,01,840$ & $5,58,989$ & $36.11 \%$ & $10,31,904$ & $19.56 \%$ \\
\hline $2013-14$ & $2,42,888$ & $6,38,596$ & $38.03 \%$ & $11,33,943$ & $21.42 \%$ \\
\hline $2014-15$ & $2,65,772$ & $6,95,792$ & $38.20 \%$ & $12,39,007$ & $21.45 \%$ \\
\hline $2015-16$ & $2,86,801$ & $7,42,295$ & $38.64 \%$ & $14,54,180$ & $19.72 \%$ \\
\hline
\end{tabular}

(Source: IT Department, Govt. Of India)

Table No. -3 is shows the ratio of personal taxes with total tax collection and total direct taxes during 2000-01 to 2015-16. Personal direct taxes to total direct taxes are decreasing. Initially, in 2000-01 the personal taxes collection is about to $46.50 \%$ of total direct taxes collection, but in consequent period it declined and by 2015-16 it was only $38.64 \%$ of total direct taxes collections. In contrast to that the ratio of personal income taxes to total taxes 
collections were increased up to 2007-08 in increasing rate but after that it fluctuated and grew unevenly. In 2015-16 it declined to $19.72 \%$ of total tax revenue. During the last 16 years personal tax collection has multiplied by 9 times whereas direct taxes and total tax revenue has multiplied by 10 times and 7 times respectively. It implies personal tax contribution in total direct tax revenue declines.

Figure 3.1:-

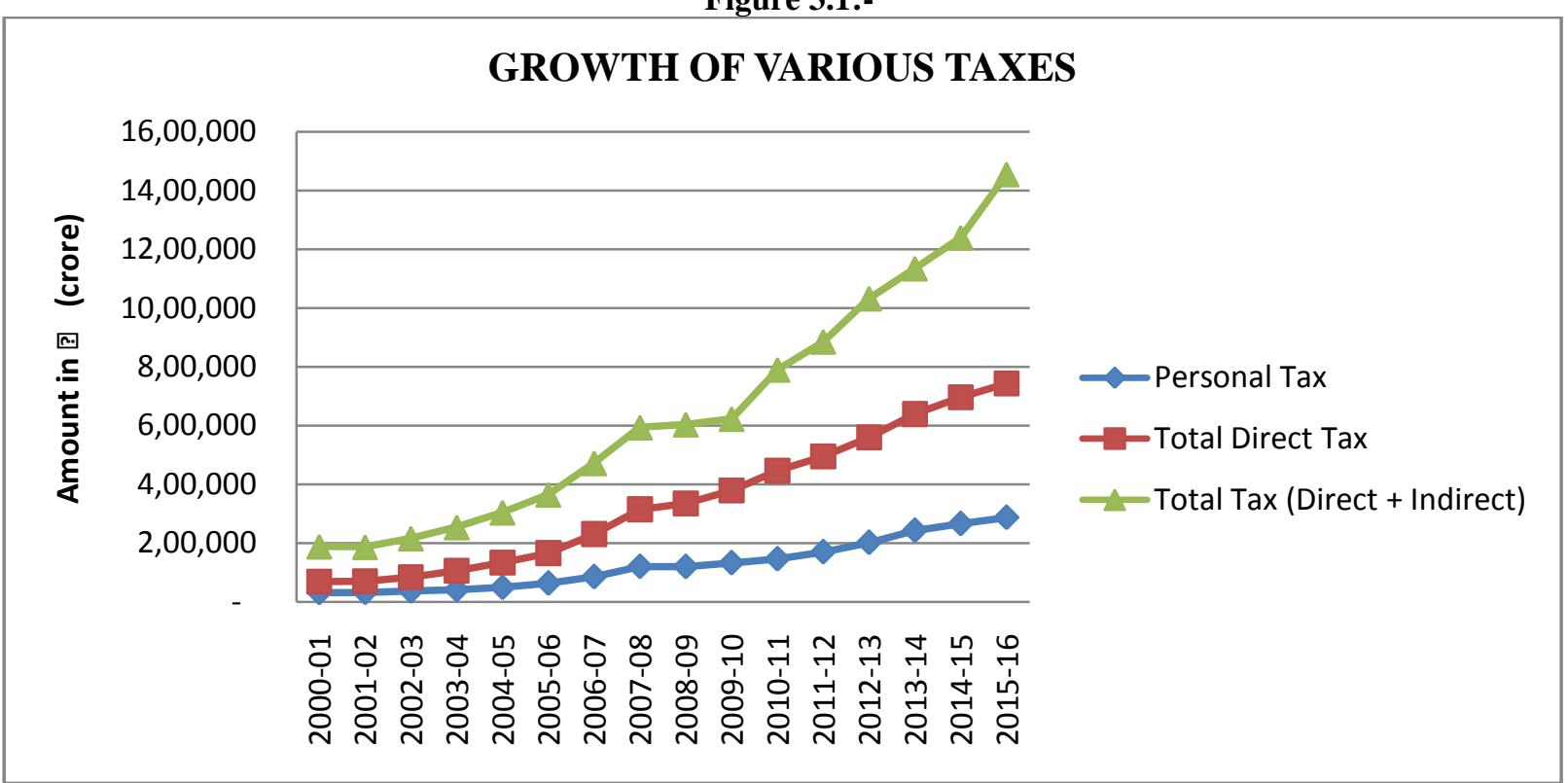

The figure 3.1 shows all three types of taxes are growing from 2000-01 to 2006-07. Due to the global slowdown and various scams took place in India the profit of various companies are adversely affected. So, during 2006-07, the all three types of taxes were affected adversely. After taking various measures by regulators the economy survived and started growing and gave positive result.

Figure 3.2:-

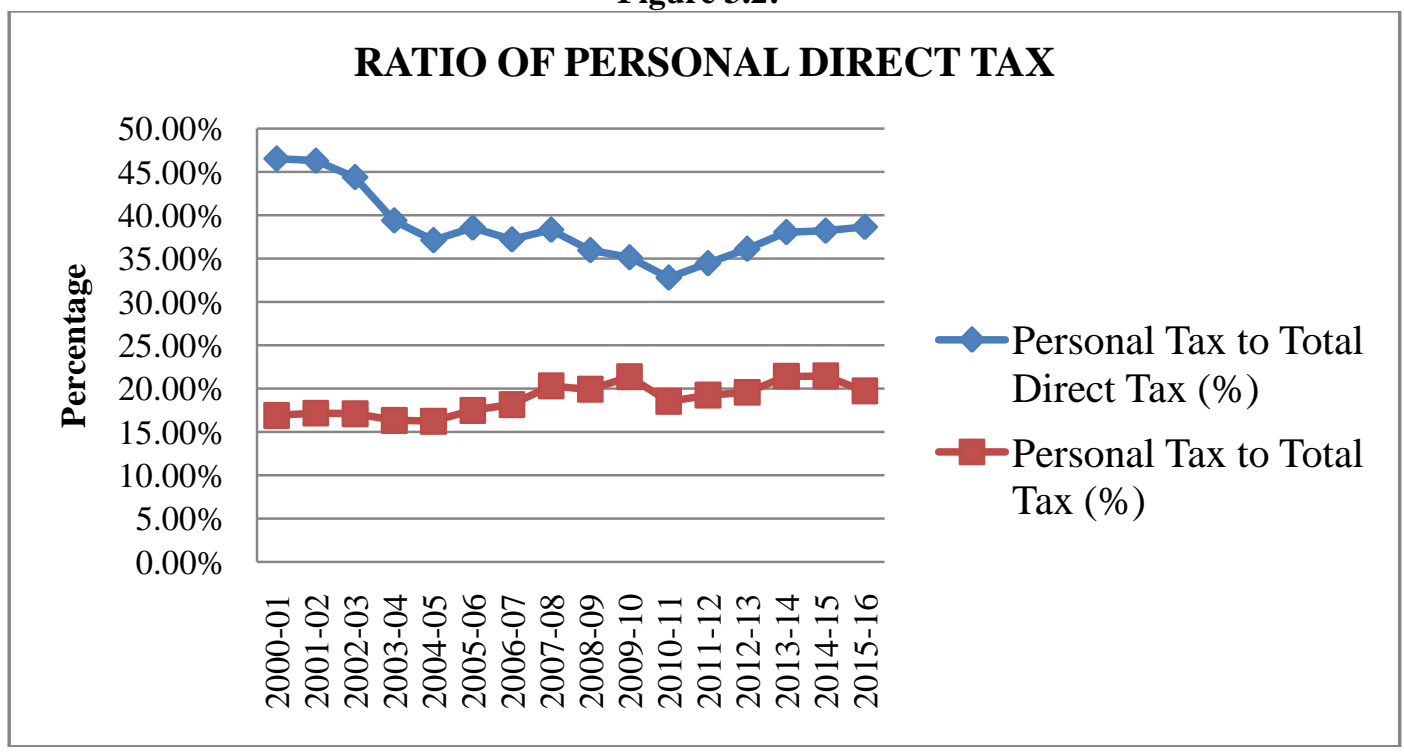

The figure 3.2 give the idea regarding the ratio of personal tax to total direct tax is in downward trend which denotes collection higher corporate tax in total direct tax. More dependence on corporate tax collection adversely affects the industries. This de-motivates the corporate in the economy. Personal tax to total tax ratio shows a very slow growth or we can say almost remain stagnant. The contribution of personal tax in both direct and total tax should be strengthened for an emerging economy. 
Table No. 4:-

\begin{tabular}{|c|c|c|c|c|c|}
\hline \multicolumn{7}{|c|}{ Corporate Tax Ratios } \\
\hline \multicolumn{7}{|c|}{$\begin{array}{c}\text { Rs. In Crores) } \\
\text { Year }\end{array}$} & Corporate Tax & $\begin{array}{c}\text { Total Direct } \\
\text { Tax }\end{array}$ & $\begin{array}{c}\text { Corporate Tax to } \\
\text { Total Direct Tax } \\
(\%)\end{array}$ & $\begin{array}{c}\text { Total Tax (Direct } \\
\text { + Indirect) }\end{array}$ & $\begin{array}{c}\text { Corporate Tax to } \\
\text { Total Tax }(\%)\end{array}$ \\
\hline $2000-01$ & 35,696 & 68,305 & $52.26 \%$ & $1,88,119$ & $18.98 \%$ \\
\hline $2001-02$ & 36,609 & 69,198 & $52.90 \%$ & $1,86,516$ & $19.63 \%$ \\
\hline $2002-03$ & 46,172 & 83,088 & $55.57 \%$ & $2,15,696$ & $21.41 \%$ \\
\hline $2003-04$ & 63,562 & $1,05,088$ & $60.48 \%$ & $2,53,696$ & $25.05 \%$ \\
\hline $2004-05$ & 82,680 & $1,32,771$ & $62.27 \%$ & $3,03,707$ & $27.22 \%$ \\
\hline $2005-06$ & $1,01,277$ & $1,65,216$ & $61.30 \%$ & $3,64,564$ & $27.78 \%$ \\
\hline $2006-07$ & $1,44,318$ & $2,30,181$ & $62.70 \%$ & $4,71,719$ & $30.59 \%$ \\
\hline $2007-08$ & $1,93,561$ & $3,14,330$ & $61.58 \%$ & $5,93,361$ & $32.62 \%$ \\
\hline $2008-09$ & $2,13,395$ & $3,33,818$ & $63.93 \%$ & $6,03,251$ & $35.37 \%$ \\
\hline $2009-10$ & $2,44,725$ & $3,78,063$ & $64.73 \%$ & $6,22,002$ & $39.34 \%$ \\
\hline $2010-11$ & $2,98,688$ & $4,45,995$ & $66.97 \%$ & $7,89,711$ & $37.82 \%$ \\
\hline $2011-12$ & $3,22,816$ & $4,93,987$ & $65.35 \%$ & $8,84,940$ & $36.48 \%$ \\
\hline $2012-13$ & $3,56,326$ & $5,58,989$ & $63.74 \%$ & $10,31,904$ & $34.53 \%$ \\
\hline $2013-14$ & $3,94,678$ & $6,38,596$ & $61.80 \%$ & $11,33,943$ & $34.81 \%$ \\
\hline $2014-15$ & $4,28,925$ & $6,95,792$ & $61.65 \%$ & $12,39,007$ & $34.62 \%$ \\
\hline $2015-16$ & $4,54,419$ & $7,42,295$ & $61.22 \%$ & $14,54,180$ & $31.25 \%$ \\
\hline
\end{tabular}

(Source: IT Department, Govt. Of India)

The Table- 4 data help us to interpret corporate tax to direct tax and total tax. In 2000-01 the corporate tax is $52.26 \%$ of total direct tax revenue. But gradually it increased and by 2010-11 it reached to $66.97 \%$. After that it started declining, by $2015-16$ it is $61.22 \%$. The corporate tax to total tax is $18.98 \%$ in $2000-01$. It increased by $20.36 \%$ in $2009-10$. Once again it started declining and come down to $31.25 \%$ in $2015-16$. The authority should take steps to bring down the much dependency on corporate tax to direct tax.

Figure 4:-

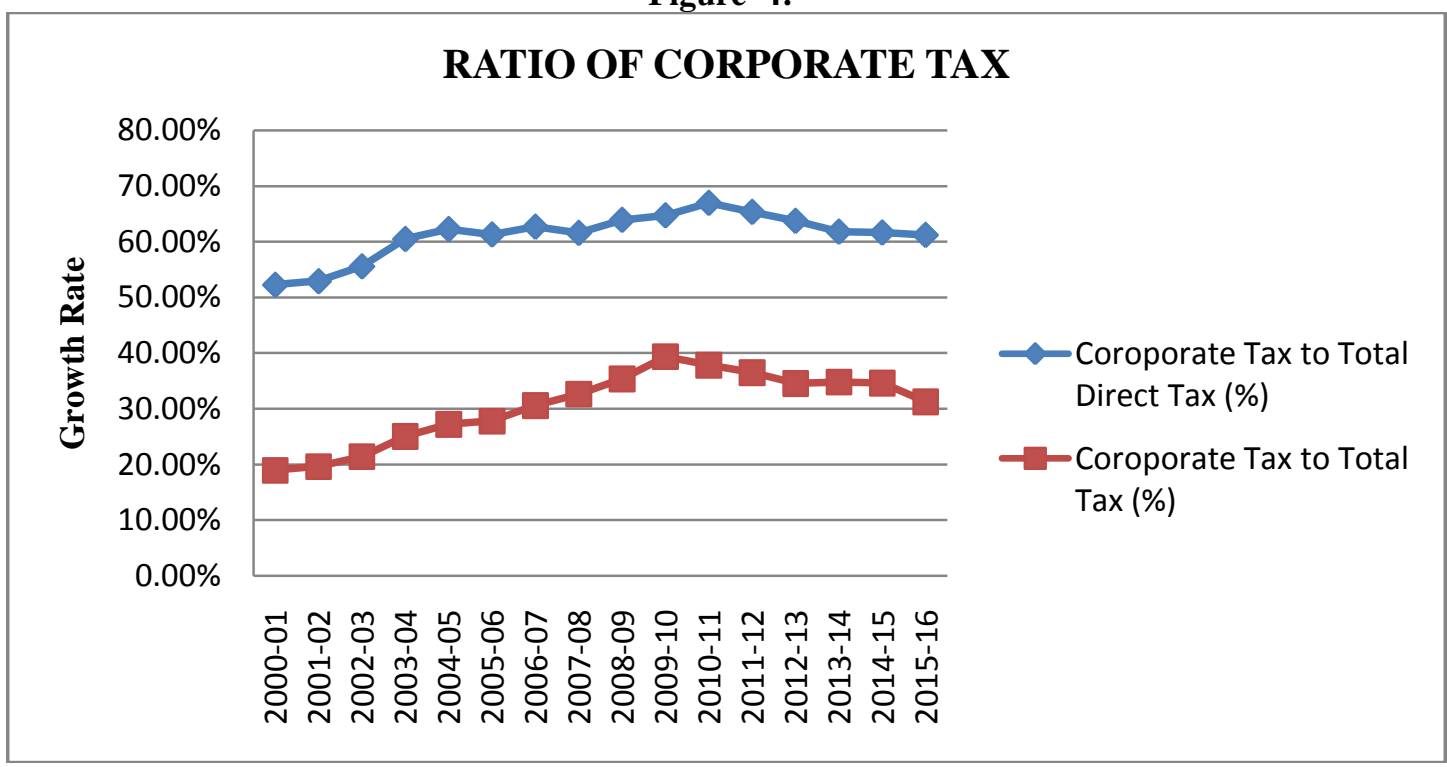

Corporate tax to total direct tax shows an uptrend during the period 2001-02 to 2010-11 as shown in figure-4, after that it shows declining trend till 2015-16. Corporate tax to total tax shows an upward trend during the period 200102 to $2009-10$, after that it declined. By, 205-16 corporate tax to total direct tax and total tax is $61.22 \%$ and $31.25 \%$ respectively. 
Table No 5:-

\begin{tabular}{|c|c|c|c|c|c|c|}
\hline \multicolumn{7}{|c|}{ TRENDS OF VARIOUS TAXES AND GDP DURING 2000-01 TO 2015-16 } \\
\hline Financial Year & $\begin{array}{c}\text { Trends of } \\
\text { Corporate } \\
\text { Tax (\%) }\end{array}$ & $\begin{array}{c}\text { Trends of } \\
\text { Personal Tax } \\
(\%)\end{array}$ & $\begin{array}{c}\text { Trends of } \\
\text { Total Tax } \\
\text { (Direct } \\
\text { Indirect) }(\%)\end{array}$ & $\begin{array}{c}\text { Trends of } \\
\text { Total Direct } \\
\text { Tax }(\%)\end{array}$ & $\begin{array}{c}\text { Trends of } \\
\text { Indirect Tax } \\
(\%)\end{array}$ & $\begin{array}{c}\text { Trends of } \\
\text { GDP Current } \\
\text { Market Price } \\
(\%)\end{array}$ \\
\hline $2000-01$ & 1.00 & 1.00 & 1.00 & 1.00 & 1.00 & 1.00 \\
\hline $2001-02$ & 2.56 & 0.76 & -0.85 & 1.31 & -2.08 & 8.50 \\
\hline $2002-03$ & 29.35 & 16.06 & 14.66 & 21.64 & 10.68 & 16.92 \\
\hline $2003-04$ & 78.06 & 30.29 & 34.86 & 53.85 & 24.03 & 31.02 \\
\hline $2004-05$ & 131.62 & 55.11 & 61.44 & 94.38 & 42.67 & 54.22 \\
\hline $2005-06$ & 183.72 & 100.51 & 93.79 & 141.88 & 66.38 & 75.68 \\
\hline $2006-07$ & 304.30 & 169.56 & 150.76 & 236.99 & 101.59 & 104.28 \\
\hline $20 / 07-08$ & 442.25 & 279.14 & 215.42 & 360.19 & 132.89 & 137.21 \\
\hline $2008-09$ & 497.81 & 277.89 & 220.68 & 388.72 & 124.88 & 167.80 \\
\hline $2009-10$ & 585.58 & 318.19 & 230.64 & 453.49 & 103.60 & 207.15 \\
\hline $2010-11$ & 736.75 & 360.45 & 319.79 & 552.95 & 186.87 & 265.02 \\
\hline $2011-12$ & 804.35 & 435.77 & 370.42 & 623.21 & 226.30 & 328.55 \\
\hline $2012-13$ & 898.22 & 535.44 & 448.54 & 718.37 & 294.71 & 381.04 \\
\hline $2013-14$ & $1,005.66$ & 664.66 & 502.78 & 834.92 & 313.43 & 440.11 \\
\hline $2014-15$ & $1,101.61$ & 736.71 & 558.63 & 918.65 & 353.38 & 496.53 \\
\hline $2015-16$ & $1,173.02$ & 802.91 & 673.01 & 986.74 & 494.16 & 545.33 \\
\hline
\end{tabular}

(Source: IT Department, Govt. Of India)

In Table No. 5 taking 2000-01 as base year by 2015-16 the growth rate of various taxes is shown. In respect to corporate tax the growth is highest in comparison to all other taxes. Its growth is near $1,173 \%$ and indirect tax is grown with least that is by $494.16 \%$. The personal tax grew by $802.91 \%$.

Figure 5:-

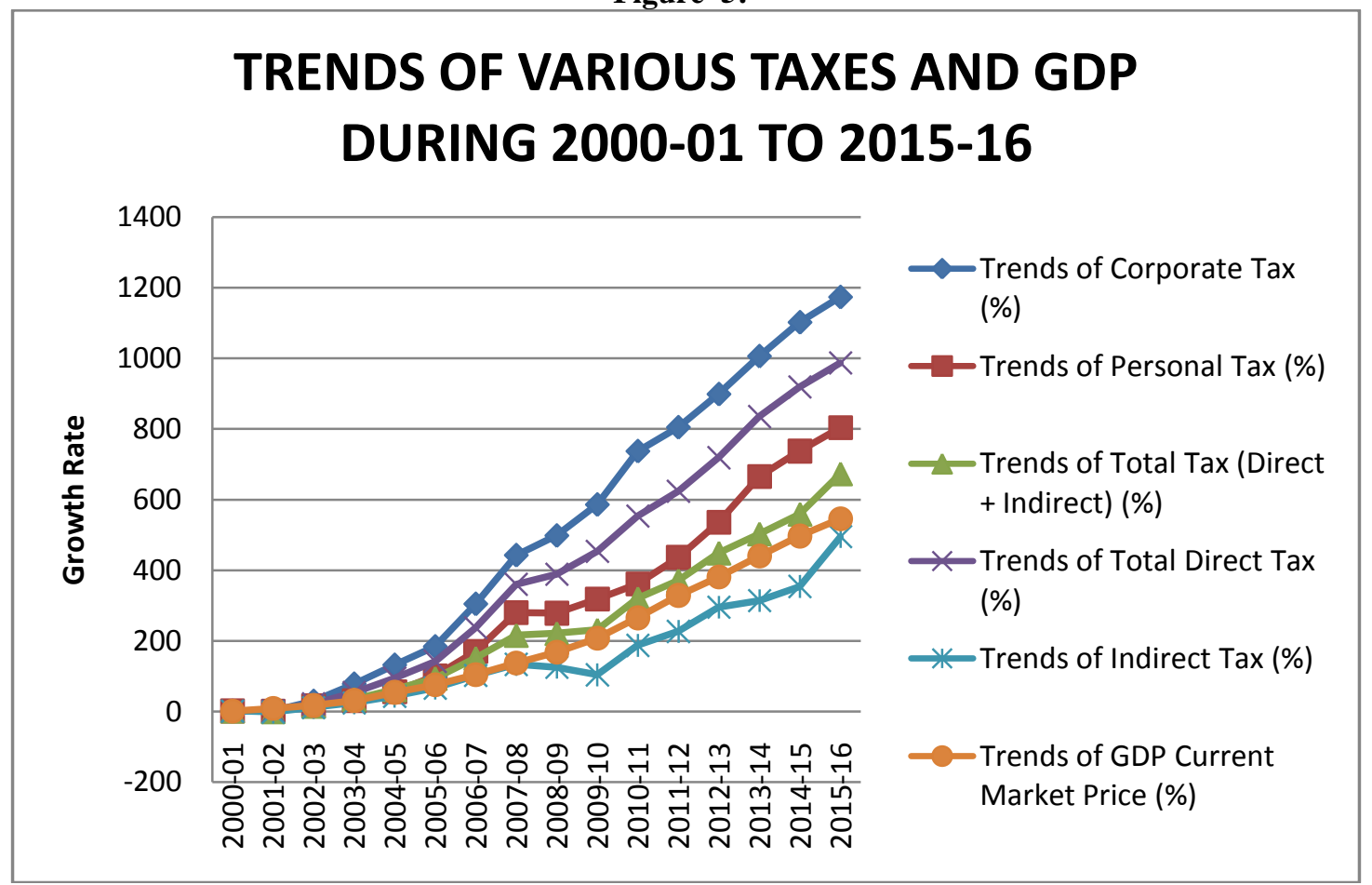


Here 2000-01 is the base year. The figure shows the growth of various ratios and GDP from base year. From 2009 onwards direct taxes trends getting steeper which is not supporting to an economy like India. Total Taxes trends above the GDP which indicates that the government is not replacing new avenues for revenue like royalty, tax on agriculture income, property taxes etc.

Tax To Gdp Ratio (Analysis):-

The Tax-to-GDP ratio is the ratio of tax collected compared to national gross domestic product (GDP). Some countries seek to increase the tax-to-GDP ratio by a certain percentage to tackle deficiencies in their budgets.

Table No. -6

\begin{tabular}{|c|c|c|c|c|}
\hline \multicolumn{5}{|c|}{ Different Taxes To Gdp Ratio } \\
\hline Financial Year & $\begin{array}{c}\text { Corporate tax as \% } \\
\text { of GDP }\end{array}$ & $\begin{array}{c}\text { Personal tax } \% \text { of } \\
\text { GDP }\end{array}$ & $\begin{array}{c}\text { Direct tax as \% of } \\
\text { GDP }\end{array}$ & $\begin{array}{c}\text { Indirect tax as \% of } \\
\text { GDP }\end{array}$ \\
\hline $2000-01$ & $1.70 \%$ & $1.51 \%$ & $3.25 \%$ & $5.70 \%$ \\
\hline $2001-02$ & $1.60 \%$ & $1.40 \%$ & $3.03 \%$ & $5.14 \%$ \\
\hline $2002-03$ & $1.88 \%$ & $1.50 \%$ & $3.38 \%$ & $5.39 \%$ \\
\hline $2003-04$ & $2.31 \%$ & $1.50 \%$ & $3.81 \%$ & $5.39 \%$ \\
\hline $2004-05$ & $2.55 \%$ & $1.52 \%$ & $4.10 \%$ & $5.27 \%$ \\
\hline $2005-06$ & $2.74 \%$ & $1.72 \%$ & $4.47 \%$ & $5.40 \%$ \\
\hline $2006-07$ & $3.36 \%$ & $1.99 \%$ & $5.36 \%$ & $5.62 \%$ \\
\hline $2007-08$ & $3.88 \%$ & $2.41 \%$ & $6.30 \%$ & $5.60 \%$ \\
\hline $2008-09$ & $3.79 \%$ & $2.13 \%$ & $5.93 \%$ & $4.79 \%$ \\
\hline $2009-10$ & $3.79 \%$ & $2.06 \%$ & $5.85 \%$ & $3.78 \%$ \\
\hline $2010-11$ & $3.89 \%$ & $1.91 \%$ & $5.81 \%$ & $4.48 \%$ \\
\hline $2011-12$ & $3.58 \%$ & $1.89 \%$ & $5.48 \%$ & $4.34 \%$ \\
\hline $2012-13$ & $3.52 \%$ & $2.00 \%$ & $5.53 \%$ & $4.68 \%$ \\
\hline $2013-14$ & $3.48 \%$ & $2.14 \%$ & $5.62 \%$ & $4.36 \%$ \\
\hline $2014-15$ & $3.42 \%$ & $2.12 \%$ & $5.55 \%$ & $4.33 \%$ \\
\hline $2015-16$ & $3.35 \%$ & $2.11 \%$ & $5.47 \%$ & $5.25 \%$ \\
\hline
\end{tabular}

(Source: IT Department, Govt. Of India)

The Table No -6 shows the ratio of various tax to GDP ratio. In 2000-01 the indirect tax to GDP ratio i.e. 5.70\% is highest in comparison to other taxes. In subsequent period Indirect tax to GDP ratio declining up to 2009-10. After that it uptrend once again and reach to 5.25\%. Corporate tax to GDP ratio is is $1.70 \%$ in 2000-01 and reached to $3.89 \%$ in 2010-11 at highest level during 2000-01 to 2015-16. But after that it declining and reached to 3.35\%. The personal tax to GDP ratio reached to the peak level 2.41\% during the same period. After 2007-08 it declined up to 2011-12. It is noticed that the personal tax to GDP ratio is volatile. Direct tax to GDP ratio was $3.25 \%$ in 2000-01, except 2001-02 and it moves upward till 2007-08. Though both personal and corporate tax ratio declined in 2008-09 hence direct tax to GDP ratio also declined.

Figure 6:-

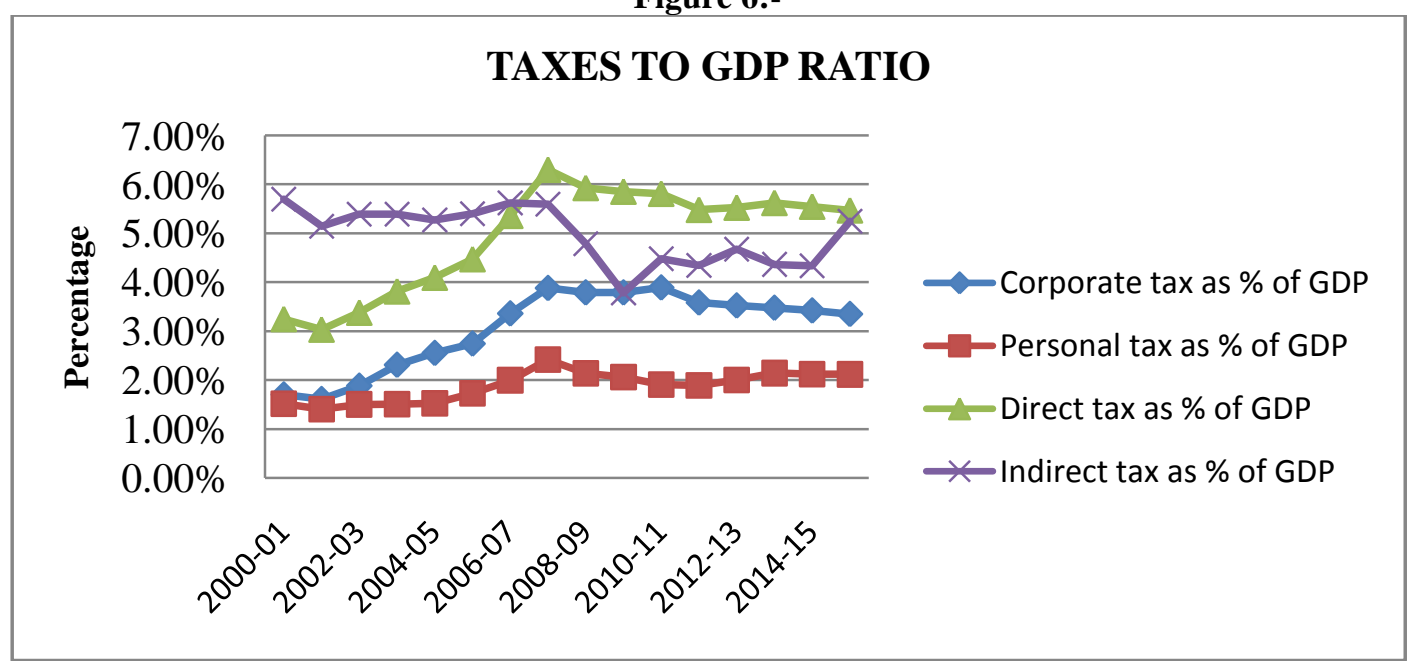


The figure-6 shows that the personal tax-GDP ratio remained low throughout 2000-01 to 2015-16. It implies that personal incomes tax contributes very less to the economy as compare to other taxes. It is an unpleasant scenario for an emerging economy. It widens the gap between poor and rich. In this case Government should either widen the tax base or increase the tax rate. But as Kelkar report suggests increasing the tax rate will lead to tax evasion, and window dressing, so widening the tax base is required. Corporate tax to GDP is just 3.25\% in 2000-01 but it increased to $5.47 \%$ by $2015-16$. In case of indirect tax to GDP ratio the rate is higher as compare to other tax ratios. More dependent on indirect tax leads to reducing the purchase power of the common man. So the indirect tax rate should be moderate. As suggested by Kelkar committee report GST should be brought as soon as possible for rationalising indirect taxes which should be associated with reducing subsidies and indirect tax rate. Subsidies are not reaching the needy. If subsidy is required to be given the DBT (Direct Benefit Transfer) should come into picture at every case as it happened with fertiliser and domestic cooking gas case brought by Government of India

\section{International Experience (Brics):-}

India is the fastest growing nation in 2015-16 and one of the emerging economies in the world. Every country wants to keep good relation with India. The relationship may either in bilateral or multilateral. India is member of various multilateral institutions. BRICS is the collaboration of Brazil, Russia, India, China and South Africa. These countries are emerging countries as like as India. So a comparison of tax to total revenue is done from 2000 to 2015 for better picture.

Table No.- 7

\begin{tabular}{|c|c|c|c|c|c|}
\hline \multicolumn{7}{|c|}{ Share Of Income Tax To Total Revenue (Brics Countries) } \\
\hline Year & Brazil & Russia & India & China & South Africa \\
\hline 2000 & NA & 8.3 & 11.3 & 12.4 & 42.3 \\
\hline 2006 & 18.7 & 8.8 & 20.4 & 24.5 & 40.8 \\
\hline 2007 & 19.4 & 9.5 & 23.6 & 23.3 & 43.3 \\
\hline 2008 & 20.5 & 10.4 & 21.3 & 24.3 & 44.4 \\
\hline 2009 & 19.9 & 12.2 & 20.5 & 22.6 & 46.6 \\
\hline 2010 & NA & 11.2 & 20.7 & 21.3 & 43.9 \\
\hline 2011 & NA & 9.6 & 20.1 & 22.0 & 41.3 \\
\hline 2012 & NA & 9.6 & 20.2 & 21.7 & 43.3 \\
\hline 2013 & NA & 10.2 & 21.4 & 22.4 & 44.4 \\
\hline 2014 & NA & 10.1 & 19.9 & 22.8 & \\
\hline 2015 & NA & 10.6 & NA & 22.5 & 46.6 \\
\hline
\end{tabular}

(Source: BRICS_Joint_Statistical_Publication_2016)

The share of income tax to total revenue ratio amongst BRICS countries shows that Brazil, China and South Africa contributes higher in comparison to India. South Africa maintains the income tax share in total revenue with around more than $40 \%$ which is good for any economy. In South Africa Income tax to total revenue in the year 2000 was $42.3 \%$. Year by year it increased and reached $46.6 \%$ in 2014. Whereas China, India and Brazil maintain their income tax to total revenue near around 20\%. Among them China has $22.5 \%$ share of income tax to total revenue in 2015. India has $19.9 \%$ in 2014. Russia's income tax ratio in total revenue is around 10.6\% in 2015.

Figure 7:-

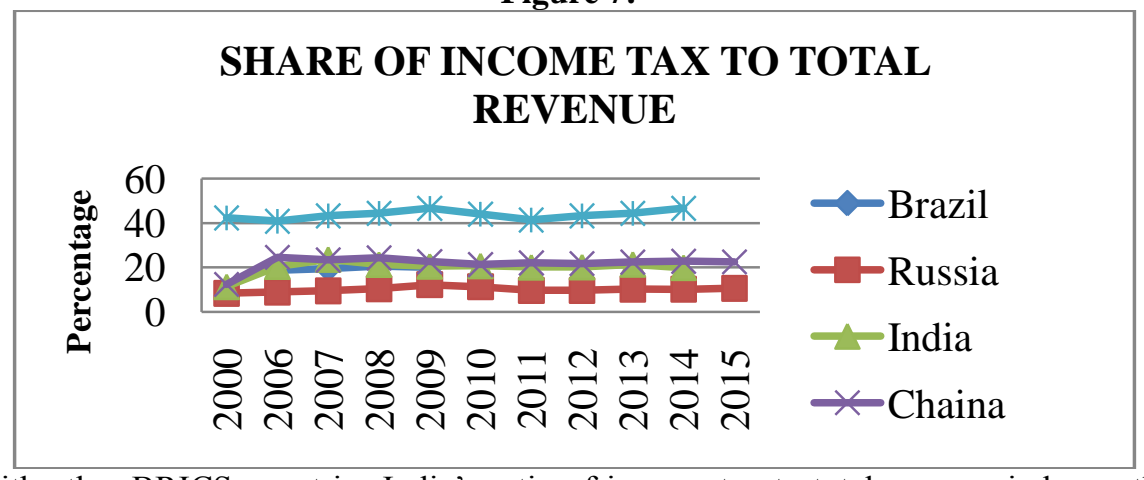

In comparison with other BRICS countries India's ratio of income tax to total revenue is lower than South Africa and China and higher than Brazil and Russia. South Africa's income tax share in total revenue is increasing; it is also the case of China. Except these two countries other three countries ratio is uneven. Taking the background of 
Russia and China which are socialist (Communist) economy and later on liberalised, it is natural the share of income tax to total revenue would not rise at a faster rate. In case of South Africa the ratio is quite high and it is presumed that perhaps individual income tax contributes more towards the resources for development.

\section{Effective Assesses And Tax Base Analsis:-}

Tax base means number of tax payers come into a particular income regime and accordingly tax slabs are fixed. As per the tax slab the assessee pay tax. In India, currently three types of tax slabs existed i.e. 2.5 lakhs to 5 lakhs (5\% slab), more than 5 lakhs to 10 lakhs (20\% slab) and more than 10 lakhs ( $30 \%$ slab).

Table No 8:-

\begin{tabular}{|c|c|c|c|c|c|c|}
\hline \multicolumn{7}{|c|}{ Comparison Of Number Of Effective Assesses With Personal Tax Collection } \\
\hline Financial Year & $\begin{array}{l}\text { Individual } \\
\text { Effective Assess }\end{array}$ & $\begin{array}{l}\text { Growth of no } \\
\text { of Individual } \\
\text { Assesses }\end{array}$ & $\begin{array}{ll}\text { Trend } & \text { of } \\
\text { Individual } & \\
\text { Assesses } & \\
\end{array}$ & $\begin{array}{lr}\text { Personal } & \text { Tax } \\
\text { Collection } & \text { (In } \\
\text { Crore) } & \\
\end{array}$ & $\begin{array}{l}\text { Growth of } \\
\text { Personal Tax } \\
\text { collection }\end{array}$ & $\begin{array}{l}\text { Trend of } \\
\text { Personal Tax } \\
\text { Collection }\end{array}$ \\
\hline $2000-01$ & $206,62,926$ & & $0.00 \%$ & 31,764 & & $0.00 \%$ \\
\hline 2001-02 & $237,34,413$ & $14.86 \%$ & $14.86 \%$ & 32,004 & $0.76 \%$ & $0.76 \%$ \\
\hline $2002-03$ & $259,35,556$ & $9.27 \%$ & $25.52 \%$ & 36,866 & $15.19 \%$ & $16.06 \%$ \\
\hline 2003-04 & $266,24,224$ & $2.66 \%$ & $28.85 \%$ & 41,386 & $12.26 \%$ & $30.29 \%$ \\
\hline 2004-05 & $247,92,990$ & $-6.88 \%$ & $19.99 \%$ & 49,268 & $19.05 \%$ & $55.11 \%$ \\
\hline $2005-06$ & $273,70,659$ & $10.40 \%$ & $32.46 \%$ & 63,689 & $29.27 \%$ & $100.51 \%$ \\
\hline 2006-07 & $293,55,248$ & $7.25 \%$ & $42.07 \%$ & 85,623 & $34.44 \%$ & $169.56 \%$ \\
\hline $2007-08$ & $308,68,243$ & $5.15 \%$ & $49.39 \%$ & $1,20,429$ & $40.65 \%$ & $279.14 \%$ \\
\hline $2008-09$ & $301,01,260$ & $-2.48 \%$ & $45.68 \%$ & $1,20,034$ & $-0.33 \%$ & $277.89 \%$ \\
\hline $2009-10$ & $313,84,084$ & $4.26 \%$ & $51.89 \%$ & $1,32,833$ & $10.66 \%$ & $318.19 \%$ \\
\hline $2010-11$ & $408,83,558$ & $30.27 \%$ & $97.86 \%$ & $1,46,258$ & $10.11 \%$ & $360.45 \%$ \\
\hline $2011-12$ & $443,46,852$ & $8.47 \%$ & $114.62 \%$ & $1,70,181$ & $16.36 \%$ & $435.77 \%$ \\
\hline $2012-13$ & $490,33,288$ & $10.57 \%$ & $137.30 \%$ & $2,01,840$ & $18.60 \%$ & $535.44 \%$ \\
\hline 20 & $486,63,680$ & $-0.75 \%$ & $135.51 \%$ & $2,42,888$ & $34 \%$ & $664.66 \%$ \\
\hline
\end{tabular}

(Source: CBDT \& IT Department, Govt. Of India)

The table no.- 8 data shows that individual assesses are growing $135.51 \%$ during 2000-01 to 2013-14 financial year. Whereas, the total direct personal tax collection grew by $664.66 \%$. The growth of number of individuals effective assesses has been doubled during this period. During the year 2010-11 the total returned filed was about 3.3\% of the total population of India whereas the ratio of returned filed by Singapore was 39\%, USA 46\%, and New Zealand $75 \%$. Since the returned filed ratio in India is very low, widening of direct tax base is required to include more people to come into the tax base.

Table No. 9:-

\begin{tabular}{|c|c|c|c|c|c|c|}
\hline \multicolumn{7}{|c|}{ Comparison Of Growth Effective Corporate Assesses With Collection Growth } \\
\hline Financial Year & $\begin{array}{c}\text { Company } \\
\text { Effective } \\
\text { Assess }\end{array}$ & $\begin{array}{c}\text { Growth of no } \\
\text { of Companies }\end{array}$ & $\begin{array}{c}\text { Trend of no of } \\
\text { Companies }\end{array}$ & $\begin{array}{c}\text { Corporate Tax } \\
\text { Collection (In } \\
\text { Crore) }\end{array}$ & $\begin{array}{c}\text { Growth of } \\
\text { Corporate tax } \\
\text { collection }\end{array}$ & $\begin{array}{c}\text { Trend of } \\
\text { Corporate tax } \\
\text { collection }\end{array}$ \\
\hline $2000-01$ & $3,34,261$ & 0 & 0 & 35,696 & 0 & 0 \\
\hline $2001-02$ & $3,49,185$ & $4.46 \%$ & $4.46 \%$ & 36,609 & $2.56 \%$ & $2.56 \%$ \\
\hline $2002-03$ & $3,65,124$ & $4.56 \%$ & $9.23 \%$ & 46,172 & $26.12 \%$ & $29.35 \%$ \\
\hline $2003-04$ & $3,72,483$ & $2.02 \%$ & $11.43 \%$ & 63,562 & $37.66 \%$ & $78.06 \%$ \\
\hline $2004-05$ & $3,73,165$ & $0.18 \%$ & $11.64 \%$ & 82,680 & $30.08 \%$ & $131.62 \%$ \\
\hline $2005-06$ & $3,82,021$ & $2.37 \%$ & $14.29 \%$ & $1,01,277$ & $22.49 \%$ & $183.72 \%$ \\
\hline $2006-07$ & $3,98,014$ & $4.19 \%$ & $19.07 \%$ & $1,44,318$ & $42.50 \%$ & $304.30 \%$ \\
\hline $2007-08$ & $4,98,066$ & $25.14 \%$ & $49.01 \%$ & $1,93,561$ & $34.12 \%$ & $442.25 \%$ \\
\hline $2008-09$ & $3,27,674$ & $-34.21 \%$ & $-1.97 \%$ & $2,13,395$ & $10.25 \%$ & $497.81 \%$ \\
\hline $2009-10$ & $3,67,884$ & $12.27 \%$ & $10.06 \%$ & $2,44,725$ & $14.68 \%$ & $585.58 \%$ \\
\hline $2010-11$ & $5,96,377$ & $62.11 \%$ & $78.42 \%$ & $2,98,688$ & $22.05 \%$ & $736.75 \%$ \\
\hline $2011-12$ & $6,54,766$ & $9.79 \%$ & $95.88 \%$ & $3,22,816$ & $8.08 \%$ & $804.35 \%$ \\
\hline $2012-13$ & $7,02,621$ & $7.31 \%$ & $110.20 \%$ & $3,56,326$ & $10.38 \%$ & $898.22 \%$ \\
\hline $2013-14$ & $7,14,419$ & $1.68 \%$ & $113.73 \%$ & $3,94,678$ & $10.76 \%$ & $1005.66 \%$ \\
\hline
\end{tabular}

(Source: IT Department and Finance Ministry, Govt. Of India) 
The corporate assesses were 3,34,261 in 2000-01 and by 2013-14 financial year their numbers uptrend to 7,14,419. It means around $113.73 \%$ growth in number of corporate tax assesses. In relation to that the corporate tax collection has grown by $1005.66 \%$. It indicates that a few number of companies are paying large amount of tax. Again as on March 2011, the total companies at work as per records of Registrar of Companies is 7,14,555 where as 5,96,377 companies have filed their Income tax return which means about 1,18,178 companies has not at all filed the return even though they are statutorily bound to file Income Tax Return.

Table No 10:-

Tax Base Of Individual Assesses For Assessment Year 2014-15

\begin{tabular}{|l|l|l|l|l|}
\hline Range (in INR) & $\begin{array}{l}\text { No of Returns (In } \\
\text { Lacs) }\end{array}$ & $\begin{array}{l}\text { Percentage of } \\
\text { No of Returns } \\
(\%)\end{array}$ & $\begin{array}{l}\text { Sum of Gross } \\
\text { Total Income (in } \\
\text { Crore INR) }\end{array}$ & $\begin{array}{l}\text { Percentage of } \\
\text { Sum of Gross } \\
\text { Total Income }\end{array}$ \\
\hline$>0$ and $<=5,00,000$ & $275,62,563.00$ & $75.49 \%$ & $7,37,756.00$ & $12.82 \%$ \\
\hline$>500,000$ and $<=10,00,000$ & $65,09,561.00$ & $17.83 \%$ & $8,10,008.00$ & $14.07 \%$ \\
\hline$>10,00,000$ and $<=20,00,000$ & $17,30,064.00$ & $4.74 \%$ & $11,30,979.00$ & $19.65 \%$ \\
\hline$>20,00,000$ and $<=50,00,000$ & $5,63,614.00$ & $1.54 \%$ & $11,03,078.00$ & $19.17 \%$ \\
\hline$>50,00,000$ and $<=1,00,00,000$ & $98,815.00$ & $0.27 \%$ & $10,63,611.00$ & $18.48 \%$ \\
\hline$>1,00,00,000$ & $48,417.00$ & $0.13 \%$ & $9,09,718.00$ & $15.81 \%$ \\
\hline Total & $365,13,034.00$ & $100.00 \%$ & $57,55,150.00$ & $100.00 \%$ \\
\hline
\end{tabular}

Source (Income Tax Return Statistics-2014-15, CBDT, Govt. Of India)

Figure 8:-

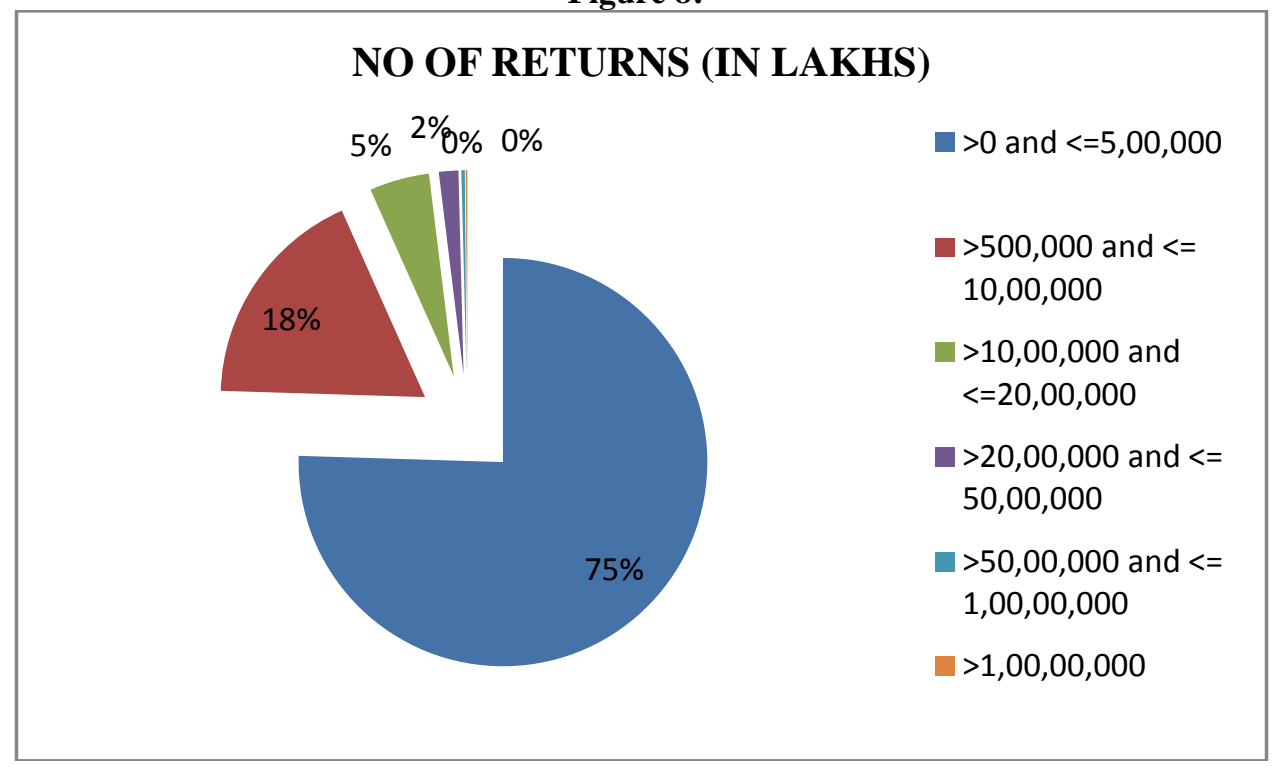

In zero to 5 lakhs income slab consisting of 2.76 crores nos of assesses which constitutes around $75 \%$ which represents that the major effective tax assessee are in low income group. In 5 to 10 lakhs slab consiting of 65 lakhs nos of assesses which constitutes around 18\% which means around $93 \%$ of effective assesses is having income below 10 lakhs and the balance 7\% which is around 7 lakhs assesses is having income of more than 10 lakhs. In contrast to that around 17.87 lakhs passenger car have purchased during the financial year 2013-14. This gap indicates that the practice of non- compliance of tax is very high in India as compared to BRICS countries and many developed and emerging economies. 
Figure 9:-

\section{PERCENTAGE OF SUM OF GROSS TOTAL INCOME}

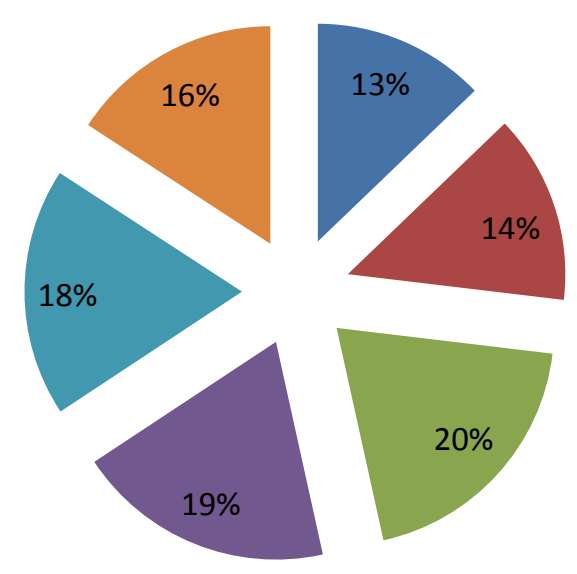

- $>0$ and $<=5,00,000$

$>500,000$ and $<=10,00,000$

$>10,00,000$ and

$<=20,00,000$

$>20,00,000$ and <=

$50,00,000$

$>50,00,000$ and <=

$1,00,00,000$

$>1,00,00,000$

The gross total income shows that $16 \%$ of total income lies with $0.13 \%$ population. 1.47 lakh assesses are above 50 lakh income category their ratio in total income is $34 \%$. There is miniscule of tax return in India i.e. around 89 lakh assesses out of 130 crore population are above the 5 lakhs income category which is less than $1 \%$ of total population. Hence their is huge gape to increase the tax base to bring more people into the tax bracket..

\section{Suggestions:-}

1. Expansion of Scope for Presumptive Taxation: Presumptive taxation involves use of indirect means to ascertain tax liability, which differ from the usual rules based on the taxpayer's accounts. Various presumptive taxation methods are in use including reconstruction of income, percentage of gross receipts, asset based taxation, industry specific methods, methods based on outward signs of life style, etc. Argentina and Mexico have adopted the asset based taxation method. Ghana applies a minimum tax based on an individual's profession or trade. France and Belgium use a contractual method based on an advance agreement between the taxpayer and tax administration to base the tax liability on estimated income instead of actual income. In Israel and France, extensive work has been done to establish prevailing profit rates in various business activities. Presumptive of tax base should be extended to other tax fields.

2. Discourage Cash Economy/ Encourage Cashless economy: The cash economy is a major handicap in the Indian economic system. Large-scale transactions are understood to take place in cash. Cash plays an important role in generation of black money. It has always been a facilitator of black money since transactions made in cash do not leave any audit trail. Unorganised sectors have remained under-taxed or untaxed. It has given rise to a large cash economy which comprises mainly the unorganised sector that tends to include small businesses, as well as high net-worth individuals. With Cashless economy the tax base shall start widening with the inclusion of the entire sector under tax net.

3. Tax on Agriculture Income: Only state government can impose/levy tax of agricultural income. This may be revisited on the light of introduction of GST- a new approach to levy of tax and again it shall help in compensating the loss incurred by state and the obligation by Central to state. The principle should be in line with ability to pay i.e. the richer farmer should not be an exception to universally recognised principles.

4. Imposition of more Tax on High Net Worth Individuals: Direct personal taxes are imposed for equity, peace, and balanced growth in the society. To fulfil this, it is essential to tax more to higher net worth individuals and use it in developmental activities where all stake holder of the society will get its benefit. 
5. Imposition of Property Tax: If better service delivery requires more resources, where can they be found? Perhaps the greatest immediate scope for revenue comes from the property tax. Property tax as a share of own revenue is above 50 per cent in Kanpur and Lucknow, but it is less than 15 per cent in Bhopal and Ranchi. So, the problem is not necessarily that Urban Local Bodies cannot raise resources because they are prevented from doing so. The major factors contributing to poor realisation from property tax are the poor assessment rate, weak collection efficiency, flawed methods for property valuation, loss on account of exemptions, and poor enforcement. In an exercise done for the Survey an attempt has been made to assess the property tax potential of Bengaluru and Jaipur using the latest satellite-based imagery. The results estimate that currently Bengaluru and Jaipur are collecting no more than 5 to 20 per cent of the property tax potential. Put differently, cities could increase their resources five to twenty fold. All efforts must be directed at realising potential of property taxes.

6. Allowance of various Deductions and Rebates: Under Direct Tax various Deductions and Rebates can be are provided and this can be availed only on Filling of Tax Returns: From various findings and with our observation we see that many people are getting deductions, rebates and subsidies without filling tax returns. Government should make mandatory provision in this regard that those who wants to get rebates or subsidies or deductions should file the returns give an affidavit in the assessment year.

7. Gradual Reduction/Withdrawal of Various Subsidies And Exemptions: Many good persons are frustrated with the way government gives subsidies and allowing exemptions to the unwanted people, those who actually want to take just advantage of this type of schemes. So Government must abolish all exemptions and subsidies and in place of that give soft loan and scrutinise in a scientific and, systematic way regularly so that chances of misuse shall be minimum.

8. Expanding Tax Base: In assessment year 2014-15, 4.87 crore people filed return which is less than $4 \%$ of total population. Domestic tax evasion is more concern than chasing black money abroad and is a testimony of India's failure to broaden its tax net. No of Salary Assessee having Income of more than 10 lacs is 11 lacs. India still have plenty of citizens who go out and buy expensive cars and jewellery but are not willing to pay the taxes to government on Income they earn. The sad fact is that all of us are too used to the freebies.

9. Inclusion of Unorganised and Rural Income under the expanded tax base: If we look at the unorganised or rural enterprises, we can see that many of them either do not know about the tax or do not want to pay tax. It is essential for an emerging economy like India to include them into the tax base. It is possible through awareness and investigation. If we can knock these sections then India's GDP as well as growth will be stronger by small contributions from this sector.

10. Reform in Tax Administrators: In India it is assumed that, why should pay so much tax, let's give some amount to government and some tax assessment officer and rest is our pocket. For example if a person is taxable income of 25 lakh for 2016-17 assessment year, then his tax liability is around 5.93 lakh. In place of showing taxable in 25 lakh he shows a profit of 15 lakh and tax liability is 2.83 lakh. If scrutiny incurred then he pay 50000 to the tax assessment officer and rest 1.6 lakh remained with the tax payer. So government should dismiss such officers and seize all the property of that tax officer. The judiciary also must support and take strong actions so that no one will think about such embezzlement. This is possible only by bringing necessary reforms and transparency in tax administration which will help building of trust between tax assessee and tax administration

\section{Conclusion:-}

There has been a good start by the present Government in widening the tax base through tax reforms both in direct and indirect taxes. At execution level the initiative should be honest and vigorous one so that the entire potential tax payers comes under its purview which in turn shall contribute to national tax revenue which shall further enable the Government to spend in providing basic social security measures and it shall also help in developing a healthy tax infrastructure in line with developed countries where the direct tax collection is lion share to total revenue. So, there is a need for creating transparent, friendlier and less discriminatory administrative system. Further there is also a need to educate the people about Indian tax law and create such an environment in which they pay their due taxes, do not evade the tax and feel proud in discharging their duty to pay the taxes. The rural India should connected to the main stream if large farmers and land holders are brought under the tax net. 


\section{References:-}

1. Aggarwal.Pawan.K. (1995)-' India: A Review of its Tax System And Recent tax reform Proposals'- Paper Presented in Symposium on Fiscal Reform an Economic

Development September 5-6, 1995 Jakarta, Indonesia pp 5-6, 39, 41

2. Agarwal P.K. (1991)-'Do Rate Schedules affect Sensitivity of Personal Income Tax? An Evidence from Developing Country-WP/01/NIPFP-New Delhi

3. Arora R.S. \& Rani Vaneeta , 2010,"Tax evasion and corruption in the Indian Income Tax System : causes and Remedies", Indian journal of Finance, Vol. 4, pp.30-36

4. Bagchi, A, 1994. "India's tax reform: a progress report", Economic and Political Weekly, vol. XXIX, 22 October, pp. 2809-2815

5. Chaurey, 2013. Location-Based Tax Incentives: Evidence From India, Columbia University Discussion Paper No.: 1213-12

6. Das Gupta et al, Income Tax Compliance in India: An empirical analysis, World Development, Vol 23 No.12, 1995

7. Dey Dr. Sanjeeb Kumar "Income Tax Department of India: A Summary Assessment, Research Journal of Finance and Accounting Vol.5, No.15, 2014, Page 118-127

8. G.S. Sahota (1991)-' Tax Payers Responsiveness to Changes in Income tax rates in India'WP/10/August'91, NIPF\&P-New Delhi pp 4-6.

9. Gupta Ankita "The Trends and Responsiveness of Personal Income Tax in India" (IGIDR Proceedings/Project Reports Series, 9-12 August 2009)

10. Jha, Shikha, 1999, "Tax Evasion, Amnesty Schemes and Black Income: Theory, Evidence and Issues", in Parikh, K.S. (ed.), India Development Report, Oxford University Press, New Delhi.

11. Jhingan M L "The Economics of Development and Planning" $35^{\text {th }}$ Revised Edition, Delhi, Varinda Publications (P) Ltd (2002)

12. Joshi, Vijay and I.M.D. Little, 1996. India's Economic Reforms 1991-2001 (New Delhi, Oxford University Press.

13. Nagaraj, G H "An Impact of Recent Income Tax Provisions on Public Finance An Analytical Study" , 2010 (Submit date- 19/10/2015), Bangalore

14. Silvani, C. and Baer, K., Designing a Tax Adninistration Reform Strategy, in Tax Notes International, August 4, 1997.

15. Singh, Jaspal \& Sharma, Poonam , 2007 "'Tax Professionals Perception of the Income Tax System of India an Empirical Evidence", The ICFAI Journal of Public Finance, Volume 5, No. 1, pp. 45-56.

16. Wadhwa Lalit, Pal Dr. Virender "Tax Evasion in India: Causes and Remedies", International Journal of Applied Engineering Research, ISSN 0973-4562 Vol.7 No.11 (2012)

17. BRICS_Joint_Statistical_Publication_2016

18. Development of an Analytical Model for Widening of Taxpayer's Base by National Institute of Public Finance and Policy (31/03/2015)

19. FISCAL POLICY STRATEGY STATEMENT (Fiscal policy in 2016-17)

20. Kelkar Vijay, 2002 ,"Report of the Task Force on Direct Taxes"

21. Third Report of the Tax Administration Reform Commission (TARC) (F. No. TARC/ Report/ 36/201415 Dated 30.11.2014)

22. Various issues of Economic survey

23. www.incometaxindia.gov.in

24. www.dor.gov.in

25. www.finmin.nic.in

26. www.indiabudget.nic.in 